\title{
Clinicopathological correlation of odontogenic cysts and tumours in a South Indian population over a 20-year period
}

\author{
Niranjan K C ${ }^{1}$, Zulfin Shaikh ${ }^{2}$ \\ ${ }^{I}$ Department of oral and maxillofacial pathology and microbiology, SDM college of dental sciences and hospital, Dharwad, Karnataka, \\ India \\ ${ }^{2}$ Department of oral and maxillofacial pathology and microbiology, SDM college of dental sciences and hospital, Dharwad, Karnataka, \\ India \\ *Corresponding author E-mail: niranjankc29@gmail.com
}

\begin{abstract}
Of several studies carried out worldwide, there is limited data available on the combined prevalence of odontogenic cysts and tumours in the Indian sub-continent. This study was designed to determine the prevalence of these lesions in the region of North Karnataka, South India over a period of 20 years. Histologically diagnosed cases of odontogenic cysts and tumours were reviewed from January 1989 to December 2008 and analyzed for age, gender and anatomical location and subjected to one way ANOVA and post Hoc statistical tests. $10.3 \%$ were odontogenic cysts and $2.13 \%$ were odontogenic tumours. Radicular cyst $(50.8 \%)$ was the most common odontogenic cyst. Odontogenic cysts were frequent in males $(63 \%)$ and anterior region of maxilla $(54.4 \%)$ with a mean age of 27.8 years. The most common odontogenic tumour was Ameloblastoma (54.8\%). Odontogenic tumours showed predilection for females (51\%) and posterior region of mandible $(68.4 \%)$ with a mean age for 29.9 years. Demographic profile of these lesions shows a distinct geographic variation.
\end{abstract}

Keywords: Demographic profile, geographic variation, North Karnataka, odontogenic cysts, odontogenic tumours.

\section{Introduction}

The mouth and the maxillofacial complex are made up of structures that are the target of a wide variety of odontogenic lesions that vary in location, etiology and histogenesis attacking soft tissue and bone, as well as presenting with variable clinical manifestations (Borges et al. 2012).

Odontogenic tumours constitute a heterogeneous group of lesions with histopathological characteristics and diverse clinical manifestations (Borges et al. 2012) derived from tooth forming apparatus, either are epithelial or ectomesenchymal or both. These tumours have a specific histological structure that reflects various stages of odontogenesis. They are rare comprising only about $1 \%$ of all tumours in the jaw (Regezi et al. 1993). The biological behaviour of these lesions ranges from hamartoma like lesions and benign neoplasms to rare aggressive malignant tumours (Gill et al. 2011). Odontogenic cysts are unique in that they only affect the oral and maxillofacial region (Jones et al. 2006). These arise from the epithelial components of the odontogenic apparatus or its remnants (Jones et al. 2006, de Souza et al. 2010) that lie entrapped within bone or in the gingival tissue (Ochsenius et al. 2007). Odontogenic cysts can be classified into inflammatory or developmental cysts according to their pathogenesis (Shear et al. 2007). Commonly odontogenic cysts exhibit slow growth but show a tendency towards expansion if not diagnosed in time and treated appropriately (de Souza et al. 2010).

Owing to the general lack of data in the English language literature on the combined prevalence of odontogenic cysts and tu mours, the aim of this study was to determine the frequency of all histologically diagnosed odontogenic cysts and tumours along with age range, sex distribution and site of presentation over a 20 year period.

\section{Material and methods}

A retrospective study was designed over a period of 20 years from January 1989 to December 2008. The data was collected from patient records and histologically diagnosed cases of odontogenic cysts and tumours were taken from the archives of Oral pathology and Microbiology, SDM College of Dental Sciences and Hospital, Dharwad, North Karnataka, India.

The inclusion criterion for odontogenic tumours was based on WHO classification 2005 where parakeratinized variant of odontogenic keratocyst was considered as Keratocystic odontogenic tumour (KOT). In the present study, parakeratinized variant of odontogenic keratocyst was considered under the category of odontogenic tumours as KOT and orthokeratinized variant under odontogenic cysts as Orthokeratinized odontogenic cyst (OOC). The odontogenic cysts diagnosed histologically as infected cysts were considered as a separate category. In the case of recurrent odontogenic cysts and tumours, the histological findings of the initial lesion and the recurrent lesion were compared and in case of similar findings were considered as a single case.

The collected data was analyzed for age, gender and anatomical location. Site distribution for maxilla and mandible was divided in two regions - anterior and posterior. Anterior region was defined from distal aspect of right canine to distal aspect of left canine. 
Posterior region was defined from mesial aspect of first premolar to distal aspect of third molar including ramus for mandibular posterior region.

The data was subjected to descriptive statistical analysis for age, gender and anatomical location and analyzed for mean and standard deviation. Statistical tests were carried out using one way ANOVA test and post Hoc tests. A p-value of $<0.05$ was considered as statistically significant.

\section{Results}

Among the 6082 oral biopsies received during 20 year period from January 1989 to December 2008, a total of 630 cases (10.3\%) of odontogenic cysts, 133 cases $(2.18 \%)$ of odontogenic tumours and 8 cases $(0.13 \%)$ of odontogenic tumours arising from odontogenic cysts were diagnosed.

Odontogenic cysts were common in males (397 cases) with predilection for anterior region of maxilla (343 cases, 54.4\%) in relation to odontogenic tumours which showed predominance in females (68 cases) and predilection for posterior region of mandible (91 cases, 68.4\%). The mean age of occurrence for odontogenic cysts and tumours was $27.78 \pm 13.4$ and $29.8 \pm 14.3$ years respectively.

Table 1 shows the frequency and gender distribution for odontogenic cysts. Of 630 cases of odontogenic cysts, 520 $(82.5 \%)$ were inflammatory cysts and $110(17.4 \%)$ were developmental cysts. Individual analysis of cysts showed radicular cyst as the most common cyst constituting $50.8 \%$ of cases followed by infected cyst (30.6\%) and dentigerous cyst (10.3\%). The diagnosis of infected cyst was given histologically based on the absence of representative epithelial lining due to excess inflammatory cell infiltration. All the odontogenic cysts had male predominance except for the calcifying odontogenic cyst.

Table 1: Frequency and gender distribution for odontogenic cysts

\begin{tabular}{|c|c|c|c|c|c|}
\hline $\begin{array}{l}\text { Odontogenic } \\
\text { cysts }\end{array}$ & $\mathrm{n}$ & $\begin{array}{l}\text { Cumulative } \\
\text { percent }\end{array}$ & Male & Female & $\begin{array}{l}\text { Ratio } \\
\text { Male:Female }\end{array}$ \\
\hline Radicular cyst & 320 & 50.8 & 196 & 124 & $1.5: 1$ \\
\hline Infected cyst & 193 & 30.6 & 122 & 71 & $1.7: 1$ \\
\hline Dentigerous cyst & 65 & 10.3 & 45 & 20 & $2.2: 1$ \\
\hline $\begin{array}{l}\text { Orthokeratinized } \\
\text { odontogenic cyst }\end{array}$ & 37 & 5.9 & 27 & 10 & $2.7: 1$ \\
\hline Residual cyst & 7 & 1.1 & 4 & 3 & $1.3: 1$ \\
\hline $\begin{array}{l}\text { Calcifying } \\
\text { odontogenic cyst }\end{array}$ & 5 & 0.8 & 2 & 3 & $1: 1.5$ \\
\hline $\begin{array}{l}\text { Lateral perio- } \\
\text { dontal cyst }\end{array}$ & 2 & 0.3 & 1 & 1 & $1: 1$ \\
\hline $\begin{array}{l}\text { Glandular } \\
\text { odontogenic cyst }\end{array}$ & 1 & 0.2 & 0 & 1 & - \\
\hline Total & 630 & 100.0 & 397 & 233 & $1.7: 1$ \\
\hline
\end{tabular}

Table 2 shows site distribution for odontogenic cysts. There was a predilection for maxilla (429 cases, $68 \%$ ) with maxilla:mandible ratio of 2.13:1. Radicular, infected and dentigerous cysts were common in the anterior region of maxilla with 179 cases $(56 \%)$ 122 cases $(63.2 \%)$ and 31 cases (48\%) respectively, but orthokeratinized odontogenic cysts were predominant in posterior region of mandible with 25 cases $(67.5 \%)$ out of total 37 cases.

Of all the odontogenic cysts, $37.1 \%$ ( 234 cases) were diagnosed during third decade with mean age of $27.7+13.4$ years. Correlation analysis revealed $60.6 \%$ of radicular cysts and $64.7 \%$ of infected cysts occurred in second and third decade. There was no statistical significant difference between age of occurrence among odontogenic cysts $\mathrm{p}=0.123$ (Table 3 ).

Among 8 cases of odontogenic tumours arising from odontogenic cysts, there were 5 cases of Ameloblastoma and 3 cases of Adenomatoid odontogenic tumour arising from dentigerous cyst. In 2 cases of Ameloblastoma, the odontogenic cyst could not be identified. These tumours were common in females and in posterior region of mandible. 3 cases occurred in third decade, 2 in fourth decades and 1 case each in second and fifth decade.
Table 2: Site distribution for odontogenic cysts

\begin{tabular}{|c|c|c|c|c|}
\hline Odontogenic cysts & $\mathrm{n}$ & $\begin{array}{l}\text { Maxilla } \\
\text { Anterior } \\
\text { Posterior }\end{array}$ & $\begin{array}{l}\text { Mandible } \\
\text { Anterior } \\
\text { Posterior }\end{array}$ & $\begin{array}{l}\text { Ratio } \\
\text { Maxilla } \\
\text { :Mandible }\end{array}$ \\
\hline Radicular cyst & 320 & $\begin{array}{l}179 \\
50\end{array}$ & $\begin{array}{l}12 \\
79\end{array}$ & $2.5: 1$ \\
\hline Infected cyst & 193 & $\begin{array}{l}121 \\
23\end{array}$ & $\begin{array}{l}10 \\
39\end{array}$ & $2.9: 1$ \\
\hline Dentigerous cyst & 65 & $\begin{array}{l}31 \\
8\end{array}$ & $\begin{array}{l}3 \\
23\end{array}$ & $1.5: 1$ \\
\hline $\begin{array}{l}\text { Orthokeratinized } \\
\text { odontogenic cyst }\end{array}$ & 37 & $\begin{array}{l}6 \\
3\end{array}$ & $\begin{array}{l}3 \\
25\end{array}$ & $1: 3$ \\
\hline Residual cyst & 7 & $\begin{array}{l}3 \\
1\end{array}$ & $\begin{array}{l}1 \\
2\end{array}$ & $1.3: 1$ \\
\hline $\begin{array}{l}\text { Calcifying } \\
\text { odontogenic cyst }\end{array}$ & 5 & $\begin{array}{l}2 \\
1\end{array}$ & $\begin{array}{l}0 \\
2\end{array}$ & $1.5: 1$ \\
\hline $\begin{array}{l}\text { Lateral periodontal } \\
\text { cyst }\end{array}$ & 2 & $\begin{array}{l}0 \\
0\end{array}$ & $\begin{array}{l}1 \\
1\end{array}$ & - \\
\hline $\begin{array}{l}\text { Glandular } \\
\text { odontogenic cyst }\end{array}$ & 1 & $\begin{array}{l}1 \\
0\end{array}$ & $\begin{array}{l}0 \\
0\end{array}$ & - \\
\hline Total & 630 & $\begin{array}{l}343 \\
86\end{array}$ & $\begin{array}{r}30 \\
171\end{array}$ & $2: 1$ \\
\hline
\end{tabular}

Table 3: Statistical analysis between age groups among odontogenic cysts Oneway ANOVA

\begin{tabular}{llllll}
\hline & $\begin{array}{l}\text { Sum of } \\
\text { Squares }\end{array}$ & Df & $\begin{array}{l}\text { Mean } \\
\text { Square }\end{array}$ & F & Significance \\
\hline $\begin{array}{l}\text { Between } \\
\text { cysts }\end{array}$ & 1820.249 & 6 & 303.375 & 1.683 & $.123^{*}$ \\
$\begin{array}{l}\text { Within } \\
\text { cysts }\end{array}$ & 112134.6 & 622 & 180.281 & & \\
Total & 113954.8 & 628 & & & \\
\hline
\end{tabular}

Table 4: Frequency and gender distribution for odontogenic tumours

\begin{tabular}{|c|c|c|c|c|c|}
\hline $\begin{array}{l}\text { Odontogenic } \\
\text { tumours }\end{array}$ & $\mathrm{n}$ & $\begin{array}{l}\text { Cumulative } \\
\text { percent }\end{array}$ & Male & Female & $\begin{array}{l}\text { Male:Female } \\
\text { ratio }\end{array}$ \\
\hline Ameloblastoma & 73 & 54.8 & 36 & 37 & $1: 1$ \\
\hline Follicular & 24 & 32.8 & 13 & 11 & $1: 1$ \\
\hline Plexiform & 13 & 18.7 & 7 & 6 & $1: 1$ \\
\hline Acanthomatous & 6 & 8.2 & 4 & 2 & $2: 1$ \\
\hline Desmoplastic & 4 & 5.4 & 2 & 2 & $1: 1$ \\
\hline Unicystic & 26 & 35.6 & 10 & 16 & $1: 1.6$ \\
\hline $\begin{array}{l}\text { Keratocystic } \\
\text { odontogenic } \\
\text { tumour }\end{array}$ & 32 & 24 & 13 & 19 & $1: 1.4$ \\
\hline $\begin{array}{l}\text { Adenomatoid } \\
\text { odontogenic } \\
\text { tumour }\end{array}$ & 10 & 7.5 & 3 & 7 & $1: 2.3$ \\
\hline Odontome & 8 & 6 & 5 & 3 & $1.6: 1$ \\
\hline $\begin{array}{l}\text { Calcifying epi- } \\
\text { thelial } \\
\text { odontogenic } \\
\text { tumour }\end{array}$ & 3 & 2.2 & 3 & 0 & - \\
\hline $\begin{array}{l}\text { Odontogenic } \\
\text { myxoma }\end{array}$ & 2 & 1.5 & 1 & 1 & $1: 1$ \\
\hline $\begin{array}{l}\text { Odontogenic } \\
\text { fibroma }\end{array}$ & 1 & 0.8 & 1 & 0 & - \\
\hline $\begin{array}{l}\text { Ameloblastic } \\
\text { fibroma }\end{array}$ & 1 & 0.8 & 1 & 0 & - \\
\hline $\begin{array}{l}\text { Malignant } \\
\text { ameloblastoma }\end{array}$ & 3 & 2.2 & 2 & 1 & $2: 1$ \\
\hline Total & 133 & 100.0 & 65 & 68 & $1: 1$ \\
\hline
\end{tabular}

Of the 133 cases of odontogenic tumours, 130 were benign and 3 were malignant. Of the latter, all 3 were malignant ameloblastomas. Among 130 benign tumours, Ameloblastoma was the most common tumour $(54.8 \%)$ followed by keratocystic odontogenic tumour (24\%). Unicystic ameloblastoma (35.6\%) was the most common variant of ameloblastoma followed by follicular ameloblastoma (32.8\%). Gender analysis for odontogenic tumours in general showed approximately equal predilection with male:female ratio of 1:1.06. All subtypes of ameloblastoma showed male predominance except for unicystic ameloblastoma (Table 4).

The mandible was the most common site of occurrence with predilection for posterior region in most of the odontogenic tumours including subtypes of ameloblastoma. Adenomatoid odontogenic 
tumour was commonly encountered in the anterior region of maxilla. The overall maxilla:mandible ratio for all odontogenic tumours was 1:4.7 (Table 5).

Table 5: Site distribution for odontogenic tumours

\begin{tabular}{|c|c|c|c|c|c|}
\hline $\begin{array}{l}\text { Odontogenic } \\
\text { tumours }\end{array}$ & $\mathrm{n}$ & $\begin{array}{l}\text { Maxilla } \\
\text { Anterior } \\
\text { Posterior }\end{array}$ & & $\begin{array}{l}\text { Mandible } \\
\text { Anterior } \\
\text { Posterior }\end{array}$ & Maxilla:Mandible \\
\hline & & $1_{2}^{3}$ & & $\begin{array}{l}5^{13} \\
4\end{array}$ & \\
\hline Ameloblastoma & 73 & 0 & & 18 & $1: 17.2$ \\
\hline Follicular & 24 & 0 & & 2 & $1: 11$ \\
\hline Plexiform & 13 & 1 & & 10 & $1: 12$ \\
\hline Acanthomatous & 6 & 0 & & 2 & - \\
\hline Desmoplastic & 4 & 0 & & 4 & - \\
\hline Unicystic & 26 & $\begin{array}{ll}0 & \\
0 & \\
& 0 \\
0 & \end{array}$ & & $\begin{array}{ll} & 2 \\
2 & \\
3 & \\
22 & \end{array}$ & $1: 25$ \\
\hline $\begin{array}{l}\text { Keratocystic } \\
\text { odontogenic } \\
\text { tumour }\end{array}$ & 32 & $4^{5}$ & & $\begin{array}{l}1 \\
22\end{array}$ & $1: 25$ \\
\hline $\begin{array}{l}\text { Adenomatoid } \\
\text { odontogenic } \\
\text { tumour }\end{array}$ & 10 & 5 & 1 & $1^{3}$ & $1.5: 1$ \\
\hline Odontome & 8 & 1 & 1 & $\begin{array}{l}0 \\
6\end{array}$ & $1: 3$ \\
\hline $\begin{array}{l}\text { Calcifying epi- } \\
\text { thelial } \\
\text { odontogenic } \\
\text { tumour }\end{array}$ & 3 & 0 & 1 & $\begin{array}{l}1 \\
1\end{array}$ & $1: 2$ \\
\hline $\begin{array}{l}\text { Odontogenic } \\
\text { myxoma }\end{array}$ & 2 & 0 & 0 & $\begin{array}{l}0 \\
2\end{array}$ & - \\
\hline $\begin{array}{l}\text { Odontogenic } \\
\text { fibroma }\end{array}$ & 1 & 0 & 0 & $\begin{array}{l}0 \\
1\end{array}$ & - \\
\hline $\begin{array}{l}\text { Ameloblastic } \\
\text { fibroma }\end{array}$ & 1 & 0 & 0 & $\begin{array}{l}1 \\
0\end{array}$ & - \\
\hline $\begin{array}{l}\text { Malignant } \\
\text { ameloblastoma }\end{array}$ & 3 & 0 & 1 & $\begin{array}{l}0 \\
2\end{array}$ & $1: 2$ \\
\hline Total & 133 & $9 \begin{array}{ll}14 \\
\end{array}$ & & $\begin{array}{c}19 \\
91 \\
\end{array}$ & $1: 4.7$ \\
\hline
\end{tabular}

Age distribution of odontogenic tumours showed Ameloblastoma with a peak in fourth decade with age range from second to fifth decade $(84.8 \%)$. Keratocystic odontogenic tumour and Adenomatoid odontogenic tumour showed peak incidence in third decade $(28 \%)$ and second decade $(50 \%)$ respectively. There was a significant difference in age of occurrence between odontogenic tumours (Table 6).

Table 6: Statistical analysis between age groups for odontogenic tumours Oneway ANOVA

\begin{tabular}{llllll}
\hline & $\begin{array}{l}\text { Sum of } \\
\text { Squares }\end{array}$ & Df & $\begin{array}{l}\text { Mean } \\
\text { Square }\end{array}$ & F & Significance \\
\hline $\begin{array}{l}\text { Between } \\
\text { tumours }\end{array}$ & 4213.216 & 11 & 383.020 & 2.029 & $.031^{*}$ \\
$\begin{array}{l}\text { Within } \\
\text { tumours }\end{array}$ & 23971.374 & 127 & 188.751 & & \\
Total & 28184.590 & 138 & & & \\
\hline
\end{tabular}

\section{Discussion}

The incidence and epidemiological behavior of odontogenic lesions exhibits geographical variations in different regions of the world. These lesions occur frequently in gnathic bones and represent around $2.5 \%$ of all the lesions biopsied in the dental services (Borges et al. 2012).

Odontogenic cysts (OCs) occurred more frequently than odontogenic tumours in the present study. This data correlates with the results of Daley et al. (1994), Camisasca et al. (2005) and Borges ${ }^{\text {et }}$ al. (2012) in terms of high frequency of cystic lesions of odontogenic origin. This may be due to the fact that odontogenic tumours remain painless throughout the course of the disease pro- cess, thus patients do not present until the tumours have reached enormous sizes (Tawfik \& Zyada 2010).

OCs is one of the most common lesions affecting the jaws and many of these cysts share similar clinical and radiographic features (de Souza et al. 2010). Therefore, the diagnosis of OCs should be based on careful examination of clinical, radiographic and histopathologic features (Ramachandra et al. 2011). In the present study, odontogenic cysts accounted for $10.3 \%$ of all oral and maxillofacial biopsies, which is consistent with the findings reported in previous studies involving populations from Brazil and Chile (Ochsenius et al. 2007, Prockt et al. 2008). Study involving Iranian population showed a high frequency of odontogenic cysts with $33.8 \%$ but a low frequency of $7.8 \%$ was seen in Mexican population (Mosqueda-Taylor et al. 2012, Sharifian \& Khalili 2007).

From the current literature it appears that odontogenic cysts account for $0.8 \%$ to $45.9 \%$ of all submitted specimens. This range is large and probably reflects the result of differences in referral practice (Jones et al. 2006). In addition, some of the studies are biased towards specific age groups such as children, this may account for the low incidence of particular cysts in some reports (Das \& Das 1993, Gultelkin et al. 2003). Results may also have been influenced by consideration of parakeratinized odontogenic keratocyst as Keratocystic Odontogenic tumour which has an impact in terms of frequency rate of odontogenic cyst diagnosis (Philipsen 2005).

In the present study, odontogenic cysts occurred in men more frequently than in women (M:F=1.7:1), this can be justified with the increased incidence of radicular cysts in men and these findings are in accordance with other reported studies in literature (Mosqueda-Taylor et al. 2002, Bataineh et al. 2004, Jones et al. 2006, Meningaud et al. 2006, Varinauskas et al. 2006, Ochsenius et al. 2007, Prockt et al. 2008, Avelar et al. 2009, Sanatkhani et al. 2011, Lawal et al. 2012) but in contrast to the report by Borges et al. (2012) who reported increased incidence of odontogenic cysts in the female gender. Maxilla was the most commonly affected site $(68 \%)$, but the findings differ from the studies by Meningaud et al. (2006), Avelar et al. (2009), Sanatkhani et al. (2011) and Lawal et al. (2012) where the mandible was the commonly affected site. As for the age distribution, the peak incidence of odontogenic cysts was between 20 and 29 years consistent with the findings of other studies (Ochsenius et al. 2007, Avelar et al. 2009, Borges et al. 2012), although the work conducted by Bento et al. (1996) and Santos et al. (2001) showed that cysts of odontogenic origin are common between the ages of 11 and 20 .

Our results showed $74.8 \%$ of inflammatory cysts which was slightly higher according to the range between $58.2 \%$ to $74.3 \%$ as observed in other studies involving different populations (Bataineh et al. 2004, Jones et al. 2006, Meningaud et al. 2006, Ochsenius et al. 2007). On the other hand, studies involving populations from Mexico demonstrated a higher frequency of developmental cysts (55.5\%) (Mosqueda-Taylor et al. 2002). It is postulated that the socioeconomic conditions of the population might influence the relative frequency of inflammatory and developmental OCs (De Souza et al. 2010). Mosqueda-Taylor et al. (2002) observed a higher frequency of developmental OCs in patients seen at a private clinic and a higher proportion of inflammatory OCs in patients attended at a public health services suggesting that among private dental practitioners there is a higher frequency of application of radiographic diagnostic methods when one or more teeth have failed to erupt.

The relative incidence of most common cysts (radicular, dentigerous, OOC) was variable with other studies such as Kreidler et al. (1993) from Germany $(56.9 \%, 21.3 \%, 10.6 \%)$, Daley et al. (1994) from Canada $(65.1 \%, 24 \%, 4.8 \%)$, Nakamura et al. (1995) from Japan $(41.2 \%, 27 \%, 7.7 \%)$, Arotiba et al. (1998) from Nigeria $(61.9 \%, 19 \%, 14.3 \%)$, Ledesma-Montes et al. (2000) from Mexico(38.8\%, 35.5\%, 18.8\%), Mosqueda Taylor et al. (2002) $(39.9 \%, 33 \%, 21.5 \%)$, Bataineh et al. (2004) from Jordan $(41.7 \%, 24.8 \%, 6 \%)$ and Shear \& Speight (2007) from South Africa $(52.3 \%, 16.6 \%, 11.2 \%)$. In the present study, radicular cyst 
was the most common cyst accounting for $50.8 \%$ of all odontogenic cysts. This finding is similar to other studies where radicular cyst constituted for more than $50 \%$ of all the odontogenic cysts (Mosqueda-Taylor et al. 2002, Jones et al 2006, Ochsenius et al. 2007, Avelar et al. 2009, Ramachandra et al. 2011). The prevalence of radicular cysts in the present study was higher in males $(61.2 \%)$ than the female gender $(38.7 \%)$. This may be explained by the fact that women are less likely to neglect their teeth and that there is a higher frequency of trauma to the maxillary anterior teeth and untreated caries in male patients (Mosqueda-Taylor et al. 2002). The most frequently affected site was the anterior maxilla (Ledesma-Montes et al. 2000, Bataineh et al. 2004, Jones et al. 2006, Ochsenius et al. 2007) in contrast to the studies reported by Meningaud et al. (2006) and Avelar et al. (2009). This can be due to esthetic reasons, as the patients wish to preserve their anterior teeth without adequate restorative endodontic treatment (Ramachandra et al. 2011). Dentigerous cyst was the most common developmental odontogenic cyst with the relative frequency of $10.3 \%$ in contrast to other studies (Bataineh et al. 2004, Meningaud et al. 2006, Pechalova \& Bakardjiev 2009, De Souza et al. 2010, Sharifian \& Khalili 2011). A study by Waldron et al. (1995) showed upper third molar to be the most prevalent site. A large variation in the relative incidence of odontogenic keratocysts exists between various studies ranging from $5.2 \%$ to $16.8 \%$ among cases that had been previously coded as KOT. In relation to gender, there was male predominance (M-72.9\%; M:F $=2.7: 1)$ which is similar with the pooled data of all OOC cases reported in English literature (2.26:1) (Wright 1981, Li et al. 1998, Dong et al. 2010).

Glandular odontogenic cysts, lateral periodontal cysts and Residual cysts were less prevalent with $0.2 \%, 0.3 \%$ and $1 \%$ of all the odontogenic cysts respectively. A high incidence of residual cysts was reported by Batista et al. (2004) (4.9\%) \& Jones et al. (2006). This variation in the incidence of residual cysts may be due to the difference in the prevalence of inflammatory cysts in various populations and the treatment protocol followed by the surgeons and general dental practitioners in the treatment of these cysts. A definite conclusion for other cysts cannot be drawn due to less number of cases reported (Avelar et al. 2009).

The lining of odontogenic cysts shows a potential for neoplastic transformation to non odontogenic malignancies like squamous cell carcinoma and mucoepidermoid carcinoma and odontogenic tumors like Ameloblastoma and Adenomatoid odontogenic tumor (AOT) (Masthan et al. 2011). In the present study, there were $0.13 \%$ cases of odontogenic tumours arising from odontogenic cysts which were considered as a separate category. There is uncertainty whether the lining of an associated cyst represents a true odontogenic cyst, a cystic change in a odontogenic tumour or represents a distinct entity (Sandhu et al. 2010). Approximately $50 \%$ of Ameloblastomas arise from the epithelial lining of a dentigerous cyst and in the present study only $0.04 \%$ cases were reported (Cankurtaran et al. 2010).

The literature on the relative frequency of odontogenic tumors from India is scarce. In the present study, 133 cases of odontogenic tumors were diagnosed over a span of 20 years constituting $2.18 \%$ of all the cases in contrast to the studies carried out in Chile and Brazil where the incidence was $1.29 \%$ and $1.3 \%$ respectively (Ochsenius et al. 2002, Pereira et al. 2012). Ameloblastoma was the most common odontogenic tumor $(54.8 \%)$ followed by keratocystic odontogenic tumour (KOT) (24\%) in contrast to the findings of Avelar et al. (2008), Luo et al. (2009) and Pereira et al. (2012) and where KOT was the most prevalent odontogenic tumour. Most of the odontogenic tumors (87.2\%) occurred during second to fifth decade with only 5 cases reported below the age of 10 years. In most permanent teeth, crown formation completes by the age of 4 to 5 years which indicates that odontogenic tumours probably develop after crown formation (Sato et al. 1997, Tanaka et al. 1999). This strengthens the fact that majority of odontogenic tumours arise from quiescent remnants of the tooth germ (Sriram \& Shetty 2008). There was an equal gender distribution with male: female ratio of 1:1.04 but a female predominance was reported by Regezi et al. (1978) and Wu \& Chan (1985)

In the present study, unicystic ameloblastoma was the most common histological variant $(35.6 \%)$ followed by follicular ameloblastoma (32.8\%) in contrast to Odukoya (1995) where acanthomatous type was the most predominant variant among 76 cases of ameloblastoma and follicular ameloblastoma was the most prevalent histological variant $(64.9 \%)$ in suburban Nigerian population (Ladeinde et al. 2005). Unicystic ameloblastoma showed female predilection $(61.5 \%)$ in contrast to other variants. KOT was the second most prevalent odontogenic tumour in this study $(24 \%)$ with the peak age of occurrence in third decade of life with female predominance (59.3\%) similar to study by Avelar et al. (2008) and in contrast to the findings of Ahlfors et al. (1984). Mandibular molar area (68.7\%) was the most affected site similar to previous reports (Luo et al. 2009, Gill et al. 2011, Pereira et al. 2012). Adenomatoid odontogenic tumor accounted for $7.5 \%$ of all odontogenic tumors and occurred in much younger age as compared to other odontogenic tumors with a female predilection (70\%) and the most common site being anterior maxilla (50\%). Younger age of occurrence for AOT may be due to the fact that this tumour is more frequent in anterior region which might alert the individual to seek attention at an earlier age and secondly, the patient may seek consultation concerning failure of the associated anterior teeth to erupt (Sriram \& Shetty 2008).

Odontomes occurred with a relative frequency of $6 \%$ which is much lower compared to the reports from USA, Canada, Mexico, Chile and Argentina (Regezi et al. 1978, Taylor et al. 1997, Santos et al. 2001, Ochsenius et al. 2002, Guerrisi et al. 2007). The incidence of calcifying epithelial odontogenic tumor (CEOT), odontogenic myxoma, ameloblastic fibroma and odontogenic fibroma was $2.2 \%, 1.5 \%$ and $0.8 \%$ respectively. All the CEOT cases were seen in males but odontogenic myxoma had equal gender distribution with predilection for mandible. Santos et al has reported a higher frequency of ameloblastic fibroma (AF) and odontogenic fibroma in maxilla (Santos et al. 2001).

\section{Conclusion}

It can be concluded that there are marked geographic differences in relative incidences of various odontogenic cysts and tumours individually and combined. In the present study, there was a high incidence of odontogenic cysts than odontogenic tumours. Odontogenic cysts and tumours had predilection for certain ages, gender and sites. Radicular cyst was the most common odontogenic cyst. Ameloblastoma was the most common odontogenic tumour with equal gender predilection followed by Keratocystic odontogenic tumour. Further studies including large series of odontogenic cysts and tumours should be performed in different regions of the world in order to determine the definite global epidemiologic profile of these lesions.

\section{Acknowledgements}

We wish to thank Dr. Srinath Thakur, Principal, SDM college of Dental Sciences and Hospital, Dharwad, Dr. Kaveri Hallikeri, Professor and Head, Department of Oral and Maxillofacial Pathology, Dr. Amsavardani Tayaar @ Padmini. S, Professor, Department of Oral and Maxillofacial Pathology and Dr. M V Muddapur, Statistician, SDM College of Dental Sciences and Hospital, Dharwad for their valuable support in the course of the study.

\section{References}

[1] Ahlfors E, Larsson A, Sjögren S (1984) The Odontogenic keratocyst: A benign cystic tumor. Journal of Oral Maxillofacial Surgery 42, 1019. 
[2] Arotiba JT, Lawoyin JO, Obiechina AE (1998) Pattern of occurrence of odontogenic cysts in Nigerians. Eastern African Medical Journa 75, 664-666.

[3] Avelar RL, Antunes AA, Carvalho RW, Bezerra PG, Neto PJ, Andrade ES (2009) Odontogenic cysts; a clinicopathological study of 507 cases. Journal of Oral Science 51,581-6.

[4] Avelar RL, Antunes AA, Santos T, Andrade E, Dourado E (2008) Odontogenic tumors: clinical and pathological study of 238 cases. Revista Brasileira de Otorrinolaringologia 74,668-73.

[5] Bataineh AB, Rawashdeh MA, Al Qudah MA (2004) The prevalence of inflammatory and developmental odontogenic cysts in a Jordanian population: A clinicopathologic study. Quintessence Internationa 35,815-9.

[6] Bento PM, Souza LB, Pinto LP (1996) Estudo epidemiologico dos cistos odontogenicos: analise de 446 casos. Revista Odonto Ciência $11,125-42$

[7] Borges LB, Fechine FV, Mota MRL, Sousa FB, Alves APNN (2012) Odontogenic lesions of the jaw: a clinical-pathological study of 461 cases. Revista Gaúcha de Odontologia Destaques 60, 71-78.

[8] Camisasca DR, Janini MER, Silva Junior JA, Bernardo V (2005) Cistos e tumores odontogenicos: estudo epidemiologico. Revista da Associação Paulista de Cirurgiões Dentistas 59,261-6.

[9] Cankurtaran CZ, Branstetter BF, Chiosea SI, Barnes EL (2010) Ameloblastoma and Dentigerous Cyst Associated with Impacted Mandibular Third Molar Tooth. Radio Graphics 30, 1415-1420.

[10]de Souza LB, Núñez MAG, Nonaka CFW, De Medeiros MC, Torres TF, Emiliano GBG (2010) Odontogenic cysts: Demographic profile in a Brazilian population over a 38 -year period. Medicina Oral Patologia Oral y Cirugia Bucal 15,583-90.

[11]Daley TD, Wysocki GP, Pringle GA (1994) Relative incidence of odontogenic tumors and oral and jaw cysts in a Canadian population. Oral Surgery Oral Medicine Oral Pathology 77,276-80.

[12]Das S, Das AK (1993) A review of pediatric oral biopsies from a surgical pathology service in a dental school. Pediatric Dentistry $15,208-11$.

[13]Dong Q, Pan S, Sun LS, Li TJ (2010) Orthokeratinized Odontogenic Cyst: A Clinicopathologic Study of 61 Cases. Archives of Pathology \& Laboratory Medicine 134, 271-275.

[14]Gill S, Chawda J, Jani D (2011) Odontogenic tumors in Western India (Gujarat): Analysis of 209 cases. Journal of Clinical and Experimenta Dentistry 3, 78-83.

[15]Guerrisi M, Piloni MJ, Keszler A (2007) Odontogenic tumors in children and adolescents. A 15-year retrospective study in Argentina. Medicina Oral Patologia Oral y Cirugia Bucal 12,180-5.

[16]Gultelkin SE, Tokman B, Turkseven MR (2003) A review of paediatric oral biopsies in Turkey. International Journal of Dentistry 53, 26 32 .

[17]Jones AV, Craig GT, Franklin CD (2006) Range and demographics of odontogenic cysts diagnosed in a UK population over a 30 -year period. Journal of Oral Pathology and Medicine 35,500-7.

[18]Kreidler JF, Raubenheimer EJ, van Heerden WF (1993) A retrospective analysis of 367 cystic lesions of the jaw-the Ulm experience. Journal of Craniomaxillofacial Surgery 21,339-41.

[19]Ladeinde AL, Ajayi OL, Ogunlewe MO, Adeyemo WL, Arotiba GT, Bamgbose BO (2005) Odontogenic tumors: A review of 319 cases in a Nigerian teaching hospital. Oral Surgery Oral Medicine Oral Pathology Oral Radiology Endodontology 99,191-5

[20]Lawal AO, Adisa AO, Sigbeku OF (2012) Cysts of the oro-facia region: A Nigerian experience. Journal of Oral Maxillofacial Pathology $16,167-171$.

[21]Ledesma-Montes C, Herna'ndez-Guerrero JC, Garce's-Orti’z M (2000) Clinico-pathologic study of odontogenic cysts in a Mexican sample population. Archives of Medical Research 31,373-6.

[22]Li TJ, Kitano M, Chen XM (1998) Orthokeratinized odontogenic cyst: a clinicopathological and immunocytochemical study of 15 cases. Histopathology 32, 242-251.

[23]Luo HY, Li TJ (2009) Odontogenic tumors: A study of 1309 cases in a Chinese population. Oral Oncology 45, 706-711.

[24]Masthan KMK, Rajkumari S, Deepasree M, Babu1 NA, Sankari SL (2011) Neoplasms associated with odontogenic cysts. Journal of Dentistry and Oral Hygiene 3, 123-130.

[25]Meningaud JP, Oprean N, Pitak-Arnnop P, Bertrand JC (2006) Odontogenic cysts: A clinical study of 695 cases. Journal of Oral Science 48, 59-62.

[26]Mosqueda-Taylor A, Irigoyen-Camacho ME, Diaz-Franco MA, Torres-Tejero MA (2002) Odontogenic cysts: Analysis of 856 cases Dental Medical clinic 7, 89-96.

[27]Nakamura T, Ishida J, Nakano Y, Ishi T, Fukumoto M, Izumi H et a (1995) A study of cysts in the oral region: Cysts of the jaws. Journa of Nihon University School of Dentistry 37, 33-40.
[28]Ochsenius G, Escobar E, Godoy L, Peñafiel C (2007) Odontogenic Cysts: Analysis of 2.944 cases in Chile. Medicina Oral Patologia Oral y Cirugia Bucal 12, 85-91.

[29] Ochsenius G, Ortega A, Godoy L, Penafiel C, Escobar E (2002) Odontogenic tumors in Chile: a study of 362 cases. Journal of Oral Pathology and Medicine 31,415-20.

[30]Odukoya O (1995) Odontogenic tumours: Analysis of 289 Nigerian cases. Journal of Oral Pathology and Medicine 25,454-7.

[31]Pechalova PF, Bakardjiev AJ (2009) Cysts of the Jaws: a Clinical Study of 621 Cases. 43, Acta stomatologica Croatica 215-224.

[32]Pereira da-Costa DO, Maurício AS, Silvestre de-Faria PA, Esmeraldo da-Silva L, Taylor AM, Chaves Lourenço SQ (2012) Odontogenic tumors: A retrospective study of four Brazilian diagnostic pathology centers. Medicina Oral Patologia Oral y Cirugia Bucal 17,389-94.

[33]Philipsen HP (2005) Keratocystic odontogenic tumor. WHO Classification of Tumors: Pathology and genetics of head and neck tumors. Lyon: IARC Press, pp. 306-7.

[34] Prockt AP, Schebela CR, Maito FDM, Filho MSA, Rados PV (2008) Odontogenic Cysts: Analysis of 680 Cases in Brazil. Head and Neck Pathology 2,150-156.

[35] Ramachandra P, Maligi P, Raghuveer HP (2011) A cumulative analysis of odontogenic cysts from major dental institutions of Bangalore city: A study of 252 cases. Journal of Oral and Maxillofacial Pathology $15,1-5$

[36] Regezi JA, Kerr DA, Courtney RM (1978) Odontogenic tumors: analysis of 706 cases. Journal of Oral Surgery 36, 771-778.

[37] Regezi JA, Sciubba J (1993) Oral pathology Clinical-pathologic correlations. WB Saunders, Philadelphia, pp. 362-397.

[38]Sanatkhani M, Zarch HH, Pakfetrat A, Falaki F (2011) Odontogenic Cysts: a Clinical and Radiographic Study of 58 Cases. Australian Journal of Basic \& Applied Sciences 5, 329-333.

[39]Sandhu SV, Narang RS, Jawanda M, Rai S (2010) Adenomatoid odontogenic tumour associated with dentigerous cyst of the maxillary antrum: A rare entity. Journal of Oral and Maxillofacial Pathology 14 24-8.

[40]Santos JN, Pinto LP, Figueredo CRLV, Souza LB (2001) Tumores odontogenicos: analise de 127 cases. Pesquisa Odontológica Brasileira 15,308-13.

[41] Sato M, Tanaka N, Sato T, Amagasa T (1997) Oral and maxillofacial tumors in children: a review. Brazilian Journal of Oral and Maxillofacial Surgery 35, 92-95.

[42]Sharifian MJ, Khalili M (2011) Odontogenic cysts: a retrospective study of 1227 cases in an Iranian population from 1987 to 2007. Journal of Oral Science 53, 361-367.

[43] Shear M, Speight P (200) Cysts of the oral and maxillofacial regions. Oxford: Blackwell Munksgaard.

[44] Sriram G, Shetty RP (2008) Odontogenic tumors: a study of 250 cases in an Indian teaching hospital. Oral Surgery Oral Medicine Oral Pathology Oral Radiology Endodontology 105, 14-21.

[45] Tanaka N, Murata A, Yamaguchi A, Kohama G (1999) Clinical features and management of oral and maxillofacial tumors in children. Oral Surgery Oral Medicine Oral Pathology Oral Radiology Endodontology 88, 11-15.

[46] Tawfik MA, Zyada MM (2010) Odontogenic tumors in Dakahlia, Egypt: analysis of 82 cases. Oral Surgery Oral Medicine Oral Pathology Oral Radiology Endodontology 109, 67-73.

[47] Taylor MA, Montes CL, Sandoval SC, Robertson JP, Godoy Rivera LMR, Garcia AM (1997) Odontogenic tumors in Mexico: a collaborative retrospective study of 349 cases. Oral Surgery Oral Medicine Oral Pathology Oral Radiology Endodontology 84, 672-675.

[48] Varinauskas V, Gervickas A, Kavoliu-niene O (2006) Analysis of odontogenic cysts of the jaws. Medicina (Kaunas) 42, 201-7.

[49]Waldron CA (1995) Oral and maxillofacial pathology. WB Saunders, Philadelphia, pp. 493-538.

[50]Wright JM (1981) The odontogenic keratocyst: orthokeratinized variant. Oral Surgery Oral Medicine Oral Pathology Oral Radiology Endodontology 51, 609-618.

[51]Wu PC, Chan KW (1985) A survey of tumors of the jawbones in Hong Kong Chinese: 1963-82. Brazilian Journal of Oral and Maxillofacial Surgery 23, 92-102. 